A N N A L E S

UNIVERSITATIS M A R A E CURIE-SKŁODOWSKA

LUBLIN - POLONIA

VOL. XXXIV, 1

SECTIO J

2021

Uniwersytet Opolski. Wydział Nauk Społecznych

FABIAN ANDRUSZKIEWICZ

ORCID: 0000-0001-5318-3793; fabian@uni.opole.pl

\title{
Zryw nauczycielski (2019) forma zmagań o godność i prestiż krzewicieli polskiej edukacji
}

The Teacher's Strike (2019) as a Form of Struggle for the Dignity and Prestige of the Promoters of Polish Education

Propozycja Cytowania: Andruszkiewicz, F. (2021). Zryw nauczycielski (2019) formą zmagań o godność i prestiż krzewicieli polskiej edukacji. Annales Universitatis Mariae Curie-Skłodowska. Sectio J, Paedagogia-Psychologia, 34(1), 221-232. DOI: 10.17951/j.2021.34.1.221-232.

\begin{abstract}
ABSTRAKT
W artykule opisano zmagania górnośląskich nauczycieli w dążeniu do zapewnienia im stabilizacji społeczno-ekonomicznej na przykładzie miasta Bytomia w województwie śląskim. Przedstawiono liczbę protestujących placówek edukacyjnych oraz podano przybliżoną liczbę bytomskich nauczycieli biorących udział w ogólnopolskim zrywie nauczycielskim. Określono ogólne przyczyny niezadowolenia środowiska nauczycielskiego z istniejącej sytuacji w systemie edukacji, mającej bezpośredni wpływ na podjęcie akcji protestacyjnej. Ponadto zwrócono uwagę na legalność strajku w szkołach, w szczególności na podpisanie protokołu mediacyjnego, wymaganego w procedurze rozwiązywania sporów zbiorowych, oraz zgłoszenia w Państwowej Inspekcji Pracy. Ustawa o rozwiązywaniu sporów zbiorowych dokładnie określa sposoby postępowania: strajk musi być poprzedzony wystąpieniem z żądaniami do pracodawcy, rokowaniami oraz przeprowadzonymi mediacjami. Warunkiem koniecznym do podjęcia akcji strajkowej jest uczestnictwo w referendum co najmniej połowy pracowników, spośród których większość opowiada się za strajkiem. Informacje zamieszczone w artykule uzyskano z wywiadów pogłębionych przeprowadzonych z dyrektorami szkół oraz ze strajkującymi nauczycielami, a także $z$ danych statystycznych udostępnionych przez Urząd Miasta Bytom. Opisano też, jak zapewniono bezpieczeństwo bytomskim uczniom podczas trwania akcji protestacyjnej nauczycieli.
\end{abstract}

Słowa kluczowe: akcja protestacyjna; bytomscy nauczyciele; szkoła; uczniowie 
Ktoś inny zmienia świat za ciebie Nadstawia głowę, podnosi krzyk A ty z daleka, bo tak lepiej I w razie czego nie tracisz nic...

Lombard

\section{WPROWADZENIE}

W ciągu swego istnienia ludzkość dorobiła się przez stulecia bogatej historii, w kreowaniu której uczestniczyły całe pokolenia: od najmłodszych do najstarszych, od biednych do bogatych, od ludzi najniższego statusu społecznego do najwyższego. Jednakże w jej pamięci zapisali się nieliczni, i to właśnie oni wnieśli najbardziej znaczący wkład do egzystencji „Adamowego plemienia”. Byli znani ze swojej pracy lub własnej tożsamości, co odróżniało ich od innych i ukazywało ich wyjątkową osobistą, twórczą indywidualność, a w szczególności indywidualność nauczycielską. Tylko mistrz może wychować plejadę artystów z niepowtarzalną własną twórczą osobowością, zdolnych, na najwyższym poziomie, a także wykonać powierzoną mu pracę, być profesjonalistą $\mathrm{w}$ swoim zawodzie, zapewniać dobrobyt i wzrost gospodarczy swojemu krajowi, przyczyniać się do uzyskania silnej pozycji na międzynarodowym rynku pracy.

We współczesnym świecie przemiany społeczne, ekonomiczne, kulturalne i polityczne mają dynamiczny charakter, a masowy dostęp do wiedzy i informacji wytycza - zwłaszcza nauczycielom zajmującym się kształceniem młodych pokoleń - nowe zadania i kierunki rozwoju. Zadania stawiane przed nauczycielami mają charakter progresywny, co nie jest ściśle powiązane z kompensacją finansową za świadczone usługi edukacyjne. Stanowi to powód do wyrażania przez nauczycieli niezadowolenia z zaistniałej sytuacji, związanej z brakiem możliwości zapewnienia sobie i swoim rodzinom dobrostanu.

Pod pojęciem dobrostanu można rozumieć doświadczanie przez człowieka pozytywnych emocji (www5), wysoki poziom zadowolenia z życia oraz niski poziom szkodliwych nastrojów. $Z$ poczuciem dobrostanu bezpośrednio związany jest optymizm jako istotny zasób osobisty wpływający na zdrowie i samopoczucie oraz na sukcesy życiowe. Dobrostan jest ściśle sprzężony z ekonomiczną sferą człowieka - bez odpowiednich środków finansowych nauczyciele nie są w stanie zapewnić sobie i swoim rodzinom godnego rozwoju, samorozwoju, doskonalenia się oraz właściwej opieki prozdrowotnej.

Wszelkie objawy niezadowolenia i frustracji doprowadzają wcześniej czy później do akcji protestacyjnych mających na celu wyegzekwowanie pewnych żądań (nie tylko ekonomicznych), słusznych według protestujących. Zryw nauczycielski w 2019 r., zapoczątkowany w 2018 r., będący formą zmagań o godność i prestiż krze- 
wicieli polskiej edukacji, rozpoczął się 8 kwietnia. W całej Polsce odwołano lekcje i zajęcia w szkołach i przedszkolach, strajk przybrał wymiar ogólnopolski. Według Sławomira Broniarza, prezesa Związku Nauczycielstwa Polskiego (ZNP), we wtorek 9 kwietnia 2019 r. do strajku przystąpiło 74,39\% publicznych placówek edukacyjnych w Polsce (www19). Strajk to batalia nie tylko o godną płacę, lecz także o godność zawodu nauczycielskiego, o właściwe miejsce zawodu nauczyciela w codziennym życiu - tak wypowiadali się na ten temat nauczyciele w radiu TOK FM.

\section{STRAJK NAUCZYCIELI W BYTOMIU}

Bytom jest jednym z najstarszych miast historycznego Górnego Śląska (www6). Pierwsza wzmianka o miejscowości, pod nazwą Bitom, pojawiła się w czasach przynależności do Polski, jeszcze przed rozbiciem dzielnicowym (1138-1320) (www16). Był on siedzibą książąt piastowskich Księstwa Bytomskiego. Do 1532 r. pozostawał w rękach Piastów śląskich (www14), następnie stanowił własność dynastii Hohenzollernów (www8), a od 1623 r. - rodu Donnersmarcków (www7) jako Wolne Państwo Stanowe (www13). W latach 1742-1945 miasto znajdowało się w granicach Prus i Niemiec (www12) i odgrywało istotną rolę jako ośrodek gospodarczy i administracyjny lokalnego zagłębia przemysłowego (www9). Do momentu wybuchu II wojny światowej (www1) Bytom był głównym ośrodkiem organizacji narodowych, społecznych, kulturalnych i wydawniczych walczących o zachowanie polskości na Górnym Śląsku (Drabina, 2010).

Po wojnie znaczna część rodowitych mieszkańców wyemigrowała lub została wywieziona do Niemiec i dawnego ZSRR (www20), z kolei na Górny Śląsk licznie napłynęli Polacy przesiedleni (,repatriowani”) z Kresów Wschodnich (www10; www18). Dekady okresu PRL (www15) charakteryzowały się stałym naciskiem na rozwój przemysłu ciężkiego, prowadzącym do rabunkowej eksploatacji środowiskowej.

Obecnie miasto Bytom jest ważnym miejscem na kulturowej, rozrywkowej i industrialnej mapie regionu, a także miejscem pracy i życia ludzi odpowiedzialnych za wychowanie i kształcenie dzieci i młodzieży w warunkach społeczeństwa postindustrialnego. Niestety, ma już status miasta wyludniającego się (tabela 1).

Tabela 1. Ludność Bytomia w latach 1970-2018

\begin{tabular}{|c|c|c|c|c|c|c|c|}
\hline Rok & 1970 & 1980 & 1990 & 2000 & 2010 & 2017 & 2018 \\
\hline Liczba mieszkańców & 187500 & 234292 & 231206 & 195807 & 177276 & 168394 & 148874 \\
\hline
\end{tabular}

Źródło: opracowanie własne.

Na przełomie XX i XXI w. Bytom utracił miano miasta dwustutysięcznego. Aktualnie liczba osób zameldowanych tutaj na pobyt stały to zaledwie 148874 . W ciągu kilkunastu lat ubyło w Bytomiu aż 50 tys. mieszkańców, co stanowi prawie 
40\% całej bytomskiej populacji (www3). Najwięcej mieszkańców w Bytomiu było w 1987 r., ponieważ wówczas było tu zameldowanych 239800 osób (www11). Wynikało to w szczególności z wciąż trwającej hossy przemysłu węglowego i hutniczego, nierozerwalnie związanej z napływem pracowników z innych regionów kraju. Dynamikę zmiany liczby mieszkańców Bytomia w latach 1970-2018 zobrazowano na rysunku 1 .
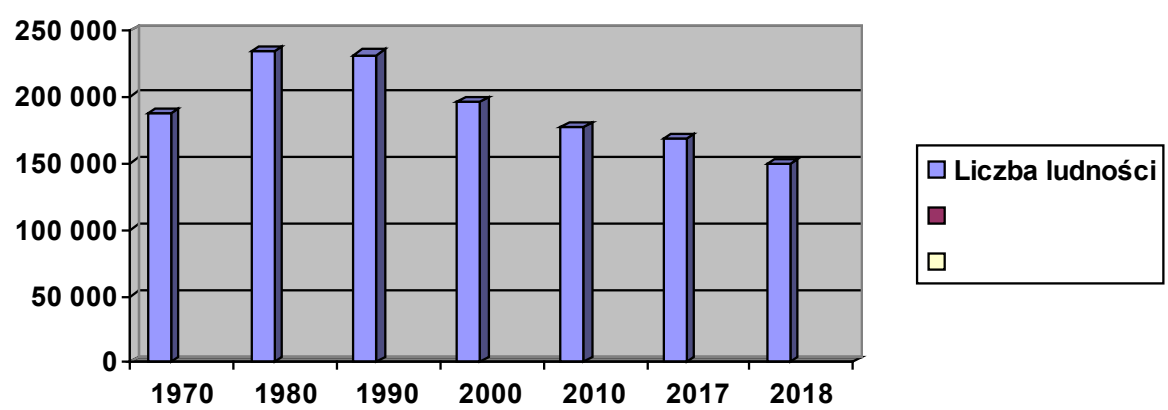

Rysunek 1. Dynamika zmiany liczby mieszkańców Bytomia w latach 1970-2018 Źródło: opracowanie własne.

Dane zamieszczone na rysunku 1 wyraźnie wskazują na dynamiczny spadek mieszkańców Bytomia, bo prawie 40-procentowy, co należy uznać za poważny cios dla tego historycznego miasta.

Pomimo rozległych zmian społeczno-gospodarczych w Bytomiu, których efektem jest zubożenie miasta, kształcenie dzieci i młodzieży niezmiennie stanowi priorytet dla bytomskich władz i nauczycieli. Obecnie w mieście funkcjonuje 86 instytucji edukacyjnych, w których zatrudnionych jest 2668 nauczycieli. Również oni dali wyraz niezadowolenia z zaistniałej w oświacie sytuacji, dołączając do ogólnopolskiej akcji protestacyjnej (www2).

W Bytomiu, podobnie jak w innych miastach w Polsce, protest miał wymiar niemal powszechny, do strajku przystąpiło bowiem 78 z 86 szkół, przedszkoli i placówek oświatowych działających w mieście, w tym: 25 szkół podstawowych, 14 szkół średnich, 32 przedszkola, 4 szkoły specjalne, 2 domy kultury, 1 poradnia psychologiczno-pedagogiczna (Nowak, 2019).

Protest bytomskich nauczycieli został przeprowadzony zgodnie z ustawą z dnia 23 maja 1991 r. o rozwiązywaniu sporów zbiorowych (Dz.U. 1991, nr 55, poz. 236). Poprzedziło go referendum przedstrajkowe, zorganizowane przez ZNP w Bytomiu, w którym udział wzięło 3633 pracowników spośród 4584 uprawnionych do głosowania. Za strajkiem opowiedziało się $88 \%$ pracowników oświaty biorących udział w referendum, natomiast pozostali byli przeciwni temu działaniu. To właśnie na nich oraz na dyrektorów szkół i przedszkoli spadł obowiązek opieki nad 
uczniami. Na podstawie głosowania stwierdzono, że w poniedziałek 8 kwietnia lekcje mogłyby się nie odbyć w 81 z 86 szkół i przedszkoli objętych działaniem ZNP na terenie miasta. Wyniki referendum były zatem bardzo zbliżone do liczby placówek edukacyjnych biorących udział w akcji protestacyjnej.

Główne przyczyny strajku bytomskich nauczycieli były praktycznie tożsame z postulatami ogólnopolskimi, czyli:

- podwyżka w wysokości $1000 \mathrm{zl,}$

- większe nakłady na oświatę z budżetu państwa,

- zmiana oceny pracy nauczycieli,

- zmiana ścieżki awansu.

- dymisja ministra edukacji.

Nauczyciele akcję strajkową zapowiadali już w grudniu 2018 r., przechodząc masowo na zwolnienia lekarskie. Pensje w szkołach nie były podwyższane od kilkunastu lat i nie były zróżnicowane, np. samodzielny referent, księgowa i woźny otrzymywali za pracę zbliżone kwoty.

Wynagrodzenie nauczycieli za pracę można określić jako niskie. Zgodnie z rozporządzeniem Ministra Edukacji Narodowej z dnia 8 lutego 2019 r. zmieniającym rozporządzenie w sprawie wysokości minimalnych stawek wynagrodzenia zasadniczego nauczycieli, ogólnych warunków przyznawania dodatków do wynagrodzenia zasadniczego oraz wynagradzania za pracę w dniu wolnym od pracy (Dz.U. 2019, poz. 249) wynosi ono w przypadku nauczyciela posiadającego tytuł zawodowy magistra z przygotowaniem pedagogicznym od 2538 zł (brutto) dla nauczyciela stażysty do $3483 \mathrm{zł}$ (brutto) dla nauczyciela dyplomowanego (tabela 2).

Tabela 2. Wynagrodzenie nauczycieli wraz ze stopniami awansu

\begin{tabular}{|c|c|c|c|c|c|}
\hline \multicolumn{2}{|c|}{ Poziom wykształcenia } & \multicolumn{2}{|c|}{ Stopnie awansu zawodowego nauczyciela } \\
\cline { 2 - 5 } & $\begin{array}{c}\text { nauczy- } \\
\text { ciel } \\
\text { stażysta }\end{array}$ & $\begin{array}{c}\text { nauczyciel } \\
\text { kontrakto- } \\
\text { wy }\end{array}$ & $\begin{array}{c}\text { nauczyciel } \\
\text { mianowany }\end{array}$ & $\begin{array}{c}\text { nauczyciel } \\
\text { dyplomo- } \\
\text { wany }\end{array}$ \\
\hline 1. & $\begin{array}{c}\text { Tytuł zawodowy magistra z przygoto- } \\
\text { waniem pedagogicznym }\end{array}$ & 2538 & 2611 & 2965 & 3483 \\
\hline $\begin{array}{c}\text { Tytuł zawodowy magistra bez przygo- } \\
\text { towania pedagogicznego, tytuł zawodo- } \\
\text { wy licencjata (inżyniera) z przygotowa- } \\
\text { niem pedagogicznym }\end{array}$ & 2250 & 2289 & 2584 & 3033 \\
\hline $\begin{array}{c}\text { Tytuł zawodowy licencjata (inżyniera) } \\
\text { bez przygotowania pedagogicznego, } \\
\text { dyplom ukończenia kolegium na- } \\
\text { uczycielskiego lub nauczycielskiego } \\
\text { kolegium języków obcych, pozostałe } \\
\text { wykształcenie }\end{array}$ & 2230 & 2250 & 2268 & 2651 \\
\hline
\end{tabular}

Źródło: załącznik do rozporządzenia Ministra Edukacji Narodowej z dnia 8 lutego 2019 r. (poz. 249). 
Z danych zawartych w tabeli 2 wynika, że nie są to kwoty wysokie i zadowalające, dlatego nauczyciele szukają dodatkowych środków i podejmują różne prace, co niekorzystnie odbija się na ich rozwoju osobistym oraz na rozwoju ucznia. „Chcemy podwyżek, żeby godnie zarabiać i nie musieć odmawiać niczego własnym dzieciom. Uważamy, że nasz zawód stracił należytą pozycję społeczną i trzeba ją odbudować" - tak argumentowała przystąpienie do strajku jedna z nauczycielek Szkoły Podstawowej nr 9 im. Adama Mickiewicza w Bytomiu, prowadząca nauczanie zintegrowane w klasach I-III, ucząca przyrody i geografii, będąca również członkiem miejskiego zarządu ZNP. Według niej podwyżki to nie wszystko, ponieważ ,nauczyciele chcą komfortowo pracować z uczniami, żeby wypełnianie dokumentacji i inne wszystkie papiery przestały ich przerastać. Nauczyciele pracują 18 godzin przy tablicy, jednakże całkowity czas pracy zdecydowanie przerasta 40 godzin, czyli wymiar pełnego etatu" (cyt. za: Osadnik, 2019).

Obok braku wzrostu płac, jako głównej przyczyny strajku nauczycieli i pracowników niepedagogicznych, wskazywano w Bytomiu także na: brak stabilizacji, wprowadzanie nieprzygotowanych reform ustroju szkolnego, obarczanie nauczycieli dodatkowymi obowiązkami (przygotowywanie konferencji, warsztatów itp.), zbyt obszerne podstawy programowe (brak czasu na rzetelne, holistyczne nauczanie), wysoką odpowiedzialność za wychowanie dzieci (brak współpracy z rodzicami i możliwości reagowania w sytuacji nieodpowiednich zachowań ucznia).

Według przewodniczącego Sojuszu Lewicy Demokratycznej Włodzimierza Czarzastego przyczyną zapowiadanego przez ZNP strajku było fatalne zarządzanie polską edukacją. Jak zaznaczył, w konflikcie między Ministerstwem Edukacji Narodowej a Związkiem Nauczycielstwa Polskiego stanął ,po stronie nauczycieli” (za: PAP, 2019).

W związku z akcją protestacyjną w Bytomiu powołano zespół kryzysowy oraz koordynatorów odpowiedzialnych za kontakt z poszczególnymi placówkami oświatowymi. Pracownicy Wydziału Edukacji Urzędu Miejskiego w Bytomiu byli w stałym kontakcie z dyrektorami placówek oświatowych, Kuratorium Oświaty, Okręgową Komisją Egzaminacyjną i Wojewodą Śląskim. Informacji udzielano w Wydziale Edukacji Urzędu Miejskiego.

W dniu 9 kwietnia 2019 r. odbyła się nadzwyczajna sesja Rady Miasta. Została ona zwołana na wniosek radnych Bytomskiej Inicjatywy Społecznej oraz Stowarzyszenia Wspólny Bytom.

Celem wnioskodawców było m.in. uzyskanie poparcia bytomskiej Rady Miasta w kwestii protestu środowiska nauczycielskiego, jednakże ten pomysł odrzucono głównie na wniosek radnych Prawa i Sprawiedliwości (PiS), którzy nie chcieli opowiedzieć się za akcją wymierzoną w rząd tworzony przez ich ugrupowanie. Nie spodobało się to reprezentującemu PiS Krzysztofowi Gajowiakowi, który wygłosił płomienne przemówienie, mówiąc: „Nauczyciele, jesteśmy z wami. Środowisko górnicze was popiera, bo pamiętamy, jak wy wyszliście na ulice w obronie likwi- 
dowanej kopalni. Jak będzie trzeba, to teraz my wyjdziemy na ulice, żeby wam pomóc" (cyt. za: www17). Wypowiedź radnego spotkała się ironicznymi wypowiedziami innych rajców. Po burzliwej naradzie Rada Miejska jednogłośnie przyjęła stanowisko popierające wzrost wynagrodzeń dla nauczycieli i pracowników niepedagogicznych. Jednocześnie, mając na względzie dobro dzieci i młodzieży, radni zaapelowali o podjęcie konstruktywnego dialogu w celu zapewnienia właściwych warunków do przeprowadzenia egzaminów. Bytomscy radni podkreślali, że dla oświaty ważne są stabilizacja oraz godne wynagrodzenie zarówno nauczycieli, jak i pracowników niepedagogicznych. Wyrazili także troskę o uczniów, którzy niebawem mieli przystąpić do ważnych egzaminów: „(...) jutro, zgodnie z planem, mają rozpocząć się egzaminy dla gimnazjalistów, a od 15 kwietnia mają je zdawać ósmoklasiści. Tylko konstruktywna dyskusja pozwoli na osiągnięcie konsensusu - argumentowali radni" (za: www4). Podjęta przez radnych uchwała trafiła do kancelarii Prezesa Rady Ministrów.

Rozpoczęty 8 kwietnia protest środowiska nauczycielskiego zaburzył funkcjonowanie polskiego, a tym samym bytomskiego systemu oświaty. Nowa sytuacja społeczna wymusiła na pracownikach pedagogicznych i niepedagogicznych, władzach oświatowych i miejskich oraz rodzicach i innych osobach nowe zachowania, adekwatne do zaistniałej sytuacji. Zwrócono uwagę na legalność strajku w szkołach, a w szczególności na podpisanie protokołu mediacyjnego wymaganego w procedurze rozwiązywania sporów zbiorowych oraz zgłoszenie w Państwowej Inspekcji Pracy. Gdyby taki protokół nie został podpisany, a nauczyciele przystąpiliby do strajku, to byłby on wówczas nielegalny, co mogłoby skutkować postępowaniami dyscyplinarnymi i odpowiedzialnością karną, a w dalszej konsekwencji pozbawieniem prawa do wykonywania zawodu.

Prezydent Bytomia i jego zastępcy na początku strajku systematycznie odwiedzali bytomskie placówki oświatowe, rozmawiali ze strajkującymi nauczycielami i sprawdzali, czy dzieci i młodzież mają prawidłowo zabezpieczoną opiekę. Prezydent Bytomia Mariusz Wołosz powiedział: „Spotkałem się ze strajkującymi nauczycielami m.in. ze Szkół Podstawowych nr 3, 9 i 46, szkół ponadpodstawowych oraz z wychowawcami przedszkoli. Nad dziećmi, które przychodzą do przedszkoli i szkół w Bytomiu, jest sprawowana opieka. Będziemy na bieżąco kontrolować sytuację. Prosimy rodziców o wyrozumiałość" (cyt. za: Mikrut-Majeranek, 2019).

Obowiązkiem dyrektorów szkół było podawanie do wiadomości Wydziału Edukacji Urzędu Miejskiego w Bytomiu liczby dzieci przebywających w szkołach podstawowych podczas strajku nauczycieli o godzinie 8:00 i 12:00 każdego dnia. Według informacji przekazanych przez dyrektorów placówek oświatowych Wydziałowi Edukacji Urzędu Miejskiego w Bytomiu w większości opiekę nad przedszkolakami i uczniami w dniach 8 i 9 kwietnia przejęli rodzice. Do szkół podstawowych, w których nauczyciele uczestniczyli w strajku, pierwszego dnia przyszło 95 uczniów, a drugiego - 70; do szkół ponadpodstawowych pierwszego 
dnia przyszło 73 uczniów, a drugiego - 63; do 32 przedszkoli biorących udział w strajku pierwszego dnia przyszło 220 dzieci, a drugiego - 240 (należy zaznaczyć, że do udziału w strajku nie przystą̧iło 9 przedszkoli).

Rodzice w tym czasie byli bardzo dobrze informowani o przebiegu strajku, dlatego większość z nich zapewniła swoim dzieciom opiekę poza szkołą. Każda szkoła i przedszkole na terenie miasta zapewniły zajęcia opiekuńcze dzieciom, które pojawiły się w placówkach. Miasto Bytom bezpłatnie zapewniło zajęcia rekreacyjne i kulturalne uczniom w halach sportowych (przy ul. Strzelców Bytomskich, Kosynierów, Frycza-Modrzewskiego), na lodowisku, w Miejskiej Bibliotece Publicznej, Bytomskim Centrum Kultury i Teatrze Rozbark. Pomoc była udzielana w miarę potrzeb poszczególnych placówek oświatowych i była uzależniona od liczby dzieci, które w dniach strajku przychodziły do szkoły. Najczęściej zajęcia prowadzili nauczyciele, katecheci lub księża, którzy do strajku nie przystąpili. Zastępcze „lekcje” prowadzone były również przez dyrektorów, którzy zgodnie z prawem nie mogą strajkować.

Na przykład nad dziećmi w Szkole Podstawowej nr 45 opiekę sprawowała Dyrektor Urszula Datko ${ }^{1}$ wraz z dwoma księżmi katechetami. W tym czasie podczas zajęć wykonywane były świąteczne wielkanocne ozdoby, dzieci tworzyły prace plastyczne oraz uczyły się różnych gier i zabaw. Należy zaznaczyć, że w tej szkole, liczącej ponad 100 nauczycieli, w strajku nie wziął udziału tylko jeden nauczyciel oraz dwóch księży katechetów. Podobnie było w innych bytomskich placówkach edukacyjnych. Zdaniem niektórych dyrektorów szkół podstawowych i gimnazjalnych (pragnących zachować anonimowość) można było pominąć egzamin ósmoklasisty oraz egzamin gimnazjalny, ponieważ rekrutacja do szkół ponadpodstawowych i ponadgimnazjalnych mogłaby się odbyć na podstawie ocen uzyskanych w trakcie procesu kształcenia w zależności od profilu dalszej edukacji.

Rodzice dzieci w większości wspierali strajkujących nauczycieli, przychodzili do szkoły, przynosili słodkości, a nawet wypożyczyli ekspres ciśnieniowy z zapasem kawy dla strajkujących. Nauczyciele raczej nie spotykali się z negatywnymi reakcjami, wręcz przeciwnie - było słychać miłe słowa, dodawano im otuchy i wsparcia. Jednakże była także grupa rodziców (około 10\%), którzy wyrażali swoje niezadowolenie w postaci negatywnych wpisów do dzienników elektronicznych, negujących przerwę w nauce dzieci. Jako przykład można wskazać ojca jednego z uczniów, który nagminnie okazywał swoje niezadowolenie, a nawet groził pociągnięciem szkoły do odpowiedzialności finansowej za ewentualne przedłużenie roku szkolnego spowodowane strajkiem, które uniemożliwiłoby wyjazd z dzieckiem na wcześniej zarezerwowane wczasy.

Rodzice swoje niezadowolenie wyrażali również w niewybredny sposób na portalach społecznościowych, zamieszczając nieprawdziwe informacje, dotyczące

1 Pani Dyrektor wyraziła zgodę na podanie swojego imienia i nazwiska. 
np. czasu pracy nauczycieli. „Wytykali” nauczycielom niski tygodniowy wymiar czasu pracy, co jest informacją daleko odbiegającą od prawdy, ponieważ czas pracy nauczyciela to nie tylko prowadzenie lekcji, lecz także szereg innych czynności wpływających na prawidłowy przebieg procesu nauczania, często przekraczający tygodniowy wymiar czasu pracy branż pozaoświatowych.

Pomimo trwającego strajku nauczyciele, których cechowała wysoka wychowawcza odpowiedzialność za kształcenie młodzieży (dotyczy to w szczególności nauczycieli przedmiotów zawodowych), prowadzili zajęcia praktyczne przygotowujące do egzaminu zawodowego, chociaż popierali strajk. Niemożliwością byłoby bowiem zdanie egzaminu zawodowego bez gruntownych umiejętności praktycznych. Taka sytuacja miała miejsce np. w Zespole Policealnych Szkół Medyczno-Społecznych w Bytomiu.

Nauczyciele za godziny strajkowe nie otrzymali wynagrodzenia, ale mieli nadzieję na otrzymanie dodatków wynikających z Karty Nauczyciela. W gminie Bytom Prezydent Miasta zabronił wypłacania jakichkolwiek środków pieniężnych, ale jednocześnie dał dyrektorom szkół „wolną rękę” w tym obszarze. Dyrektorzy nie mieli i nie mają instrumentów prawnych, aby wypłacić sporne środki, wolą więc narazić się na sprawy sądowe wytoczone przez pracowników niż na zarzut Regionalnej Izby Obrachunkowej dotyczący niegospodarności w wydawaniu środków publicznych.

Nauczyciele na początku akcji protestacyjnej nie chcieli strajkować, nie byli przygotowani na tak długo trwający protest, myśleli, że strajk będzie trwał krótko, a rząd spełni ich żądania i usatysfakcjonowani wrócą do pracy. Rzeczywistość okazała się jednak inna.

Strajk został zawieszony na wniosek ZNP od soboty 27 kwietnia od godziny 6:00 rano ze względu na rozpoczynające się od 6 maja 2019 r. egzaminy maturalne. Sławomir Broniarz powiedział: „Dajemy premierowi czas do września. W porozumieniu z uczniami, w porozumieniu z rodzicami podjęliśmy decyzję o zawieszeniu strajku, by zapewnić uczniom warunki do zakończenia nauki, ale powtarzam: zawieszamy, ale nie kończymy tego protestu”. Jak zaznaczył, to „nauczyciele, dyrektorzy szkół i rodzice musieli wziąć odpowiedzialność za uczniów".

Bytomscy nauczyciele w większości byli rozczarowani i zaskoczeni zakończeniem akcji protestacyjnej, ponieważ nastawili się na walkę do końca, aż do spełnienia wszystkich wysuniętych żądań. Duża liczba wypowiadających się nauczycieli, pragnących zachować anonimowość, opowiedziała się za strajkiem okupacyjnym, lecz wysoka odpowiedzialność kierownictwa ZNP (bo tak to można nazwać) skłoniła kierownictwo ZNP do zawieszenia strajku.. 


\section{ZAKOŃCZENIE}

Nauczyciele wykonują zawód zaufania publicznego. Jest to praca o szczególnym charakterze z punktu widzenia zadań publicznych i troski o realizację interesu publicznego. Rodzice powierzają ich opiece swoje dzieci, a Państwo - młodych obywateli, których trzeba wyedukować i wpoić im ogólnie przyjęte normy etyczne. Nietrudno sobie zatem wyobrazić, jak duży ciężar spoczywa na nauczycielu, który nie mając zapewnionych odpowiednich warunków materialno-ekonomicznych, musi zapewnić właściwy poziom nauczania i samokształcenia.

Strajk według bytomskich nauczycieli i lokalnej społeczności był i jest jak najbardziej zasadny. Bez wątpienia ukazał on niedoskonałość systemu edukacyjnego, a w szczególności podkreślił brak zapewnienia dobrostanu jego podstawowym komponentom, czyli nauczycielom i uczniom. Postulaty, jakie wysuwają nauczyciele, można uznać za uzasadnione. Warto wymienić w tym miejscu kilka z nich:

1. Zwiększenie wzrostu płac nauczycieli i pracowników niepedagogicznych, mające na celu zapewnienie stabilizacji ekonomicznej.

2. Odciążenie nauczycieli od dodatkowych obowiązków, od pisania programów nauczania, przygotowywania konferencji, warsztatów itp., czas ten należy przeznaczyć na pracę z uczniem.

3. Zwiększenie współpracy z rodzicami, umożliwienie reagowania w sytuacji nieodpowiednich zachowań ucznia w znacznym stopniu utrudniającego proces wychowawczy.

4. Wydłużenie do 15 lat awansu zawodowego jest niezwykle krzywdzące, ponieważ kobieta po studiach i urodzeniu np. czwórki dzieci oraz wykorzystaniu urlopów stopień nauczyciela dyplomowanego osiągnie w wieku, kiedy będzie miała już darmową komunikację publiczną.

5. W Bytomiu działa jedna Poradnia Psychologiczno-Pedagogiczna, pełniąca $\mathrm{w}$ większości funkcję diagnostyczną, natomiast terapeutyczną w ograniczonym zakresie. Jako jedyna poradnia w ponad stutysięcznym mieście jest bardzo „obciążona” licznymi obowiązkami, stąd okres oczekiwania na konsultację dla tzw. dziecka trudnego trwa czasami nawet dwa miesiące, dlatego nauczyciele apelują do władz o zwiększenie liczby poradni specjalistycznych.

Wszelkiego rodzaju spory, zwłaszcza w obszarze edukacyjnym, prowadzące do powstawania akcji protestacyjnych, należy rozwiązywać w pierwszym etapie ich powstawania (w tzw. zarodku). Nierozwiązane, prowadzą wprost do istotnych konfliktów społecznych, a co za tym idzie stanowią zagrożenie dla pokoju społecznego, niezmiernie ważnego i kluczowego dla harmonijnego rozwoju gospodarczego kraju. 


\section{BIBLIOGRAFIA}

\section{LITERATURA}

Drabina, J. (2010). Historia Bytomia od średniowiecza do wspótczesności 1123-2010. Bytom: Towarzystwo Miłośników Bytomia.

\section{NETOGRAFIA}

Mikrut-Majeranek, M. (2019). Za nami pierwszy tydzień strajku nauczycieli. Co z maturami w Bytomiu? Pobrane z: www.bytomski.pl/polityka/23733-za-nami-pierwszy-tydzien-strajku-nauczycieli-co-z-maturami-w-bytomiu (dostęp: 10.12.2020).

Nowak, T. (2019). Nie ma lekcji, jest protest. Pobrane z: http://zyciebytomskie.pl/index.php/ZB/ arch_art/nie-ma-lekcji-jest-protest (dostęp: 10.12.2020).

Osadnik, P. (2019). Strajk nauczycieli w Bytomiu! Lekcji nie ma w 78 szkołach i przedszkolach. Pobrane z: https://bytom.naszemiasto.pl/strajk-nauczycieli-w-bytomiu-lekcji-nie-ma-w-78-szkolach-i/ar/c1-5071429 (dostęp: 11.11.2020).

PAP. (2019). Czarzasty: Przyczyna strajku nauczycieli jest fatalne zarządzanie edukacja. Pobrane z: https://serwisy.gazetaprawna.pl/edukacja/artykuly/1401268,czarzasty-przyczyna-strajku-nauczycieli-jest-fatalne-zarzadzanie-edukacja.html (dostęp: 11.11.2020).

www1: II wojna światowa. Pobrane z: https://pl.wikipedia.org/wiki/II_wojna_\%C5\%9Bwiatowa (dostęp: 10.02.2021).

www2: bip.um.bytom.pl (dostęp: 16.06.2019).

www3: Bytom nie jest już nawet 150-tysięcznym miastem. Pobrane z: https://bytomski.pl/miasto/22926-bytom-nie-jest-juz-nawet-150-tysiecznym-miastem (dostęp: 16.01.2021).

www4: Bytomscy radni w sprawie protestu nauczycieli. Pobrane z: https://www.bytom.pl/aktualnosci/ index/Bytomscy-radni-w-sprawie-protestu-nauczycieli/idn:7051 (dostęp: 29.01.2021).

www5: Emocja. Pobrane z: https://pl.wikipedia.org/wiki/Emocja (dostęp: 10.11.2020).

www6: Górny Śląsk. Pobrane z: https://pl.wikipedia.org/wiki/Górny_Śląsk (dostęp: 12.12.2020).

www7: Henckel von Donnersmarck. Pobrane z: https://pl.wikipedia.org/wiki/Henckel_von_Donnersmarck (dostęp: 10.11.2020).

www8: Hohenzollernowie. Pobrane z: https://pl.wikipedia.org/wiki/Hohenzollernowie (dostęp: 10.11.2020).

www9: Konurbacja górnośląska. Pobrane z: https://pl.wikipedia.org/wiki/Konurbacja_g\%C3\%B3rno\%C5\%9B1\%C4\%85ska (dostęp: 19.02.2021).

www10: Kresy Wschodnie. Pobrane z: https://pl.wikipedia.org/wiki/Kresy_Wschodnie (dostęp: 10.11.2020).

www11: Ludność Bytomia. Pobrane z: https://pl.wikipedia.org/wiki/Ludno\%C5\%9B\%C4\%87_Bytomia

(dostęp: 16.01.2021).

www12: Niemcy. Pobrane z: https://pl.wikipedia.org/wiki/Niemcy (dostęp: 10.11.2020).

www13: Państwo stanowe. Pobrane z: https://pl.wikipedia.org/wiki/Państwo_stanowe (dostęp: 10.11.2020).

www14: Piastowie śląscy. Pobrane z: https://pl.wikipedia.org/wiki/Piastowie_\%C5\%9B1\%C4\%85scy (dostęp: 30.06.2019).

www15: Polska Rzeczpospolita Ludowa. Pobrane z: https://pl.wikipedia.org/wiki/Polska_Rzeczpospolita_Ludowa (dostęp: 10.11.2020). 
www16: Polska w okresie rozbicia dzielnicowego. Pobrane z: https://pl.wikipedia.org/wiki/Polska_w_okresie_rozbicia_dzielnicowego (dostęp: 12.12.2020).

www17: Radni zgodni: nauczycielom należy się podwyżka. Pobrane z: http://zyciebytomskie.pl/ index.php/ZB/arch_art/radni-zgodni-nauczycielom-naley-si-podwyka (dostęp: 12.11.2020).

www18: Wysiedlenie Polaków z Kresów Wschodnich 1944-1946. Pobrane z: https://pl.wikipedia.org/ wiki/Wysiedlenie_Polak\%C3\%B3w_z_Kres\%C3\%B3w_Wschodnich_1944\%E2\%80\%931946 (dostęp: 10.11.2020).

www19: ZNP: strajkuje ponad 74 procent placówek. Pobrane z: https://tvn24.pl/polska/strajk-nauczycieli-ile-szkol-i-przedszkoli-protestuje-ra925846-2306887 (dostęp: 29.01.2021).

www20: Związek Socjalistycznych Republik Radzieckich. Pobrane z: https://pl.wikipedia.org/wiki/ Zwi\%C4\%85zek_Socjalistycznych_Republik_Radzieckich (dostęp: 10.11.2020).

\title{
AKTY PRAWNE
}

Rozporządzenie Ministra Edukacji Narodowej z dnia 8 lutego 2019 r. zmieniające rozporządzenie w sprawie wysokości minimalnych stawek wynagrodzenia zasadniczego nauczycieli, ogólnych warunków przyznawania dodatków do wynagrodzenia zasadniczego oraz wynagradzania za pracę w dniu wolnym od pracy (Dz.U. 2019, poz. 249).

Ustawa z dnia 23 maja 1991 r. o rozwiązywaniu sporów zbiorowych (Dz.U. 1991, nr 55, poz. 236).

\begin{abstract}
The article describes the struggles of Upper Silesian teachers in the pursuit of ensuring them the socio-economic stability on the example of the city of Bytom in the Silesian Voivodeship. The number of protesting educational institutions in this city was presented, and the approximate number of Bytom teachers taking part in the nationwide teachers' strike was given. The general reasons of teachers' dissatisfaction with the existing situation in the education system have been identified, having a direct impact on taking up the protest action. In addition, attention was also paid to the legality of the strike in schools, and in particular to sign the mediation protocol required in the collective dispute resolution procedure, and the notification in the National Labor Inspectorate. The Act on the settlement of collective disputes specifies exactly how to proceed, namely: the strike must be preceded by submitting demands to employers, negotiations and mediations. A necessary condition for undertaking a strike action is participation in the referendum of at least half of the employees, where most of them are in favor of the strike. The information was obtained on the basis of in-depth interviews with school principals and teachers on strike, as well as on the basis of statistical data provided by the Bytom City Hall. The work also presents the methods of ensuring the safety of Bytom students during the teachers' protest action.
\end{abstract}

Keywords: protest action; Bytom teachers; school; students 